\title{
The Normativity Of The Principle of Mutual TRUST BETWEEN EU MEMBER STATES WITHIN THE EMERging European CRIMINAL AREA
}

\author{
ALEKSANDRA SULIMA*
}

\section{THE EUROPEAN CRIMINAL AREA - CONCEPT AND EVOLUTION}

The European Criminal Area is the expression commonly used in legal doctrine and practise for the cooperation of the EU Member States within their criminal justice systems. This term is not derived from the EU Treaties, neither from the Treaty on European Union (hereinafter: TEU ${ }^{1}$ ) nor from the Treaty on the Functioning of the European Union (hereinafter: TFEU $^{2}$ ). This term covers the complex structure of the various instruments and mechanisms functioning within the Member States. It includes the traditional international legal instruments of cooperation as well as innovative supranational methods ${ }^{3}$. However, it must be mentioned at the beginning that the EU has shifted its emphasis from the former method to the latter. Cooperation governed by the intergovernmental method always implies some political consensus during the conclusion of numerous bilateral and multilateral agreements, whereas the supranational method of cooperation requires more engagement and readiness not only from governments, but also from the organs and agencies which apply the respective law on a daily basis.

The advanced cooperation aiming at establishing a single judicial area in criminal justice within the European Union is of an unprecedented character. Under this type of cooperation, independent states decide to relinquish a part of their sovereign rights to a newly-established supranational body. The governments decide to delegate a portion of decision-making powers to a new authority. One may ask how it is possible to achieve such an advanced form of interstate cooperation between

DOI: $10.2478 /$ wrlae-2013-0006

* PhD candidate, Department of International and European Law, Faculty of Law, Administration and Economics, Wroclaw University; ola.sulima@gmail.com

${ }^{1}$ Consolidated version of the Treaty on European Union [2012] OJ C326.

${ }^{2}$ Consolidated version of the Treaty on the Functioning of the European Union [2012] OJ C326.

3 J Garstka, 'Współpraca w sprawach karnych' in F Jasiński, K Smoter (eds), Obszar wolności, bezpieczeństwa i sprawiedliwości. Geneza, stan i perspektywy rozwoju (Warsaw 2005) 341 . 
independent states. The justification for the concept of the European Criminal Area should be sought in the complex foundations of European integration. When analysing the foundations of European integration, we must take into consideration extensive historical, economic and sociocultural factors. In this broad context one can understand how such an advanced form of cooperation within an area as delicate as criminal justice could be at all possible.

First of all, it must be remembered that European integration started a few years after the end of World War II. The European Coal and Steel Community, precursor of the present EU, began building the foundations of European integration in a post-war setting. The idea of closer cooperation in the respective economic sectors was an attempt to forestall similar global conflicts. What is more, subsequent historical events had a significant impact on the general international situation. These included the collapse of colonial empires and the constant military and economic threat of the Soviet Union. All of these factors shaped the reality of the 1950s, forming the political atmosphere within the countries of western Europe which decided to tighten what were initially economic relations.

Secondly, purely economic considerations cannot be forgotten. The commercial benefits resulting from cooperation between states located in one geographical region seemed at the time to be obvious.

Thirdly, there are also some factors enabling European integration of a socio-cultural nature. European countries share a cultural background and constitute a community of common values.

This comprehensive approach to the foundations of European integration allows us to understand the particular situation within EU Member States, the situation enabling the creation of more advanced mechanisms of cooperation. Analysis of this background leads us to the concept of mutual trust as a precondition of innovative cooperation ${ }^{4}$.

At the same time, one cannot forget that historical and political dependences can sometimes constitute disintegrating factors, the so-called phenomenon of mistrust between the respective parties. However, it seems that the integrating factors within the emerging European Criminal Area are prevailing, that the concept of the EU viewed as a community of common values is well-founded and justified. Thus, it seems that cooperation between EU Member States in criminal matters based on the shared values of liberty, democracy, respect for human rights and fundamental freedoms, the rule of law and solidarity ${ }^{5}$ has overwhelming potential to create a single area of justice in criminal matters. It is said that the EU has been able to create a community of mutual fate, a community guided by the idea of solidarity, which has placed human beings and their natural rights at the centre of its interests ${ }^{6}$.

\footnotetext{
${ }^{4} \mathrm{M}$ Ficher, Mutual trust in European Criminal Law, University of Edinburgh School of Law Working Paper Series (2009/10).

5 A Grzelak, 'Wzmacnianie wzajemnego zaufania między państwami członkowskimi w obszarze współpracy w sprawach karnych jako czynnik integrujący Unię Europejską' in K Żukrowska (ed), Co dzieli, co integruje Wspólnotę Europejską? (Warsaw 2007) 411.

${ }^{6}$ K Popowicz, Rozwój podstaw prawnych Unii Europejskiej, vol. I (Warsaw 2009) 67.
} 


\section{THE CONCEPT OF MUTUAL TRUST}

Many treatises elaborating the new area of cooperation of EU Member States in criminal matters use the term "mutual trust" as a basis and a precondition for the creation of a common area of criminal justice. They often refer to the example of the single market in economic cooperation as a model for the criminal area. The substance of this commonly used phrase, however, is not clear. One should ask what this concept includes, whether the term 'mutual trust' comes from social sciences and has no legal meaning, or is a term with extra-legal roots that has acquired a legal dimension.

Initial reflections on the essence of mutual trust lead to extra-legal associations. Thus, at the beginning of the analysis of the nature of the principle of mutual trust within EU structures, we should recall the basic assumptions of the sociological theory of trust. This sociological theory implies the creation of social ties and the formation of an institutional order based on social capital. This theory is crucial for further considerations of trust and the social foundations of public order. It is emphasized, however, that the sociological theory of trust is not sufficient to explain the complex political mechanisms in the sphere of internal security and justice developed within the EU. Assuming that the aim of EU Member States cooperating with EU institutions and bodies within the European Criminal Area is to strengthen the transnational supervisory and controlling mechanisms created for ensuring internal security, the sociological context does not fully illuminate the issue. However, there is no doubt that social expectations should be taken into consideration by the institutions responsible for public order in the functioning of such mechanisms. Of particular importance is the possibility of having trust in the legality and efficiency of law enforcement authorities, which play a fundamental role in the protection of citizens and society as a whole from pathological phenomena and threats ${ }^{7}$. Finally, it should be mentioned that one cannot exclude the usefulness of the sociological theory in the course of further analysis of the principle of mutual trust and its legal aspects, as this principle has not yet been precisely defined either in the Treaties or in Court of Justice jurisprudence ${ }^{8}$.

Thus, considering that the sociological theory of trust is not alone sufficient to understand the European Criminal Area, the normative approach is invoked. This approach treats trust as a mechanism of cooperative actions based on the common norms ${ }^{9}$. The roots of this concept are to be found primarily in the general principle stipulated in Art. 4 (3) of TEU: "Pursuant to the principle of sincere cooperation, the Union and the Member States shall, in full mutual respect, assist each other in carrying out tasks which flow from the Treaties." The Court of Justice referred in its criminal cases to the principle of loyalty even before the communitarisation of the former third pillar ${ }^{10}$.

\footnotetext{
7 BA Misztal, Trust in Modern Societies. The search for the bases of social order (Cambridge 1996) chapter 1.

${ }^{8}$ Ficher (n 4) 12.

${ }^{9}$ F Fukuyama, Zaufanie. Kapitat społeczny a droga do dobrobytu (Warsaw 1997) 38.

${ }^{10}$ Ficher (n 4) 12
} 
Focusing in particular on integration in the sphere of internal security and justice, one should remember the delicate nature of this area, which has always been considered under the dominion of national sovereignty. Over the fifty years of its development, the EU has created a multi-level security structure. This structure requires strong relations between the participants involved in creating this reality. The complex decision-making mechanisms, information flows and division of powers involved create what is at times not a very transparent system, the development of which is constantly in progress and involves continual coordinating efforts and stimulation. Thus, it is said that in order to make the system function smoothly, it is necessary to achieve operational efficiency, to jointly elaborate and implement effective policies, procedures and legal instruments as well as to assure advanced technological capacities in each Member State. To link the aforementioned elements of the emerging European Criminal Area we must also fulfil another condition, namely that of mutual trust between the interested parties. This trust must be the result of the political will of parties undertaking the joint initiative, and it must also reflect a readiness to enhance cooperation stemming from faith in the reliable and responsible approach of all participants to the agreed objectives and targets ${ }^{11}$.

As far as mutual trust in cooperation regarding criminal matters is considered, both the subjective and objective scope can be recognized ${ }^{12}$. The former refers to a range of subjects invloved. It can concern state authorities as well as judicial authorities of other countries. This trust can be also be invoked in reference to vertical relations, namely between state authorities and individuals. This relationship must be interpreted broadly, going beyond the approach of state bodies to citizens. The idea of the European Criminal Area assumes that every individual should have the same high level of confidence in protection of the law within every Member State, irrespective of nationality ${ }^{13}$. Proceeding to an analysis of the objective scope of mutual trust, it must be said that this depends on the parties who are under consideration at a given moment, the nature of their interdependence and the type of cooperation. We can define the objective scope in many different ways, from general statements to very precise ones. Thus, trust can refer in general to the functioning of the national judiciary or the observance of the rule of law. Simultaneously, we can also speak of trust in sincere cooperation within certain legal instruments, e.g. trust in the reliable implementation of the Framework Decision on the European Arrest Warrant $(\mathrm{EAW})^{14}$ or in the due enforcement of a request for the surrender of a person.

The abovementioned examples of how mutual trust is required between Member States will not be analysed to an equal extent in this paper. In our consideration of the legal character of the principle of mutual

\footnotetext{
11 A Gruszczak, Wspólpraca policyjna w UE w wymiarze transgranicznym. Aspekty polityczne i prawne (Wydawnictwo Uniwersytetu Jagiellońskiego 2009) 231-232.

${ }^{12}$ Ficher (n 4) 13.

13 A Grzelak, 'Przestrzeń Wolności, Bezpieczeństwa i Sprawiedliwości' [2007] Sprawy Międzynarodowe 16.

${ }^{14}$ Council Framework Decision, (2002/584/JHA), on the European arrest warrant and the surrender procedures between Member States [2002] OJ L190/1.
} 
trust, particular emphasis will be put on the relationship between the various national legislators - the authorities which create the law - and between the various executing bodies - the authorities which apply the law. As far as national legislators are concerned, the most common method used is that of intergovernmental cooperation - the traditional model of interstate actions. However, close cooperation at the level of the application of the law constitutes a novelty within international cooperation. The authorities which apply the law should have confidence not only in the legal systems of other Member States, but more pertinently, they should have confidence in the effects of the functioning of these systems, in the judgments and decisions issued by foreign bodies, as well as in the legitimization and competence of these organs to undertake certain actions ${ }^{15}$. All of these situations require each interested party to possess knowledge about other participants. Such mutual knowledge of participants' legal systems seems to be a key aspect in the process of building the European Criminal Area. Therefore, it seems that the essence of mutual trust is not the abstract belief that the other party shall comply with the common rules, nor is it the possession of pure, objective knowledge. Trust in fact constitutes a conviction that other Member States will comply with agreed-upon rules, this assumption being based on concrete, significant knowledge ${ }^{16}$.

The statement that the crucial condition in the process of building mutual trust is increasing mutual knowledge should be complemented by the issue of the legitimization of actions ${ }^{17}$. Until the reform introduced by the Lisbon Treaty, the sphere of cooperation in criminal matters was highly criticized due to a lack of legitimacy and the lack of basic features required in democratic societies, as manifested by the weak role played by the European Parliament and national parliaments and the creation of law in isolation from the EU's citizens. The Lisbon reform has introduced, however, significant changes in this area, which can be deemed as a huge step towards reinforcing mutual trust in the emerging European Criminal Area.

To conclude these first considerations over the concept of mutual trust, it should also be emphasized that trust is, by its own nature, a dynamic phenomenon. Trust will always contain an element of risk. The process of building mutual trust between sovereign states is necessarily long, toilsome and requires the involvement of all parties. What is more, results already achieved can be lost very quickly. Thus, it has to be stressed that this process is continuous and will never be completed.

Furthermore, while one has to bear in mind this constant progress of the building of mutual trust, it also should be remembered that this process is not homogeneous. The level of already-achieved trust varies significantly in certain areas of cooperation, policy or even concrete legal instruments. The required, desired or existing degree of mutual trust between Member States may, thus, vary considerably and this should be considered when analysing every single legal institution ${ }^{18}$.

\footnotetext{
${ }^{15}$ Ficher (n 4) 13.

16 ibid 17-18.

17 ibid 17.

18 ibid 19.
} 


\section{THE CIRCUMSTANCES OF AN APPLICATION OF THE PRINCIPLE OF MUTUAL TRUST}

At first sight it may seem that at each stage of cooperation between sovereign subjects the existence of mutual trust is necessary, that there is trust that another party acts in good faith, and that it can be relied upon to implement common standards. However, the necessity of the existence of mutual trust is not a uniform requirement for all forms of cooperation within the EU; its necessity depends on the one hand on the division of powers between the EU and the Member States, as well as the nature of these competences, while on the other hand it depends on the stage of cooperation, its advancement.

Firstly, the issue of EU competences should be mentioned. The sphere of the EU's competences can be divided into exclusive (Article $2 \S 1$ and 3 TFEU) and non-exclusive forms. The latter includes shared competences (Article $2 \S 2$ of the TFEU), which were called competitive competences prior to the Lisbon Treaty, and other competences to carry out actions to support, coordinate or supplement the actions of Member States without thereby superseding their competence in these areas (Article $2 \S 5$ of the TFEU), which were previously known as parallel competences.

The area of freedom, security and justice, and thus the emerging European Criminal Area as well, have been included in the group of socalled shared powers (Article $4 \S 3$ of the TFEU) ${ }^{19}$. The idea behind this type of competence is explained in Article $2 \S 2$ TFUE, which says that: 'When the Treaties confer on the Union a competence shared with the Member States in a specific area, the Union and the Member States may legislate and adopt legally binding acts in that area. The Member States shall exercise their competence to the extent that the Union has not exercised its competence. The Member States shall again exercise their competence to the extent that the Union has decided to cease exercising its competence.' This issue is also clarified in the Protocol on the exercise of shared competence ${ }^{20}$. The Member States declared that: "when the Union has taken action in a certain area, the scope of this exercise of competence only covers those elements governed by the Union act in question and therefore does not cover the whole area.' The EU's competences within the area of freedom, security and justice therefore do not cover all issues in this field, but only those regulated by the basic act of the EU. The limitation of the EU's authority is also apparent through Article 72 TFEU, which guarantees the exclusive competence of Member States in the maintenance of public order and protecting internal security ${ }^{21}$.

When considering the application of the principle of mutual trust, the relationship between the type of competences and the existence of mutual trust must first be analysed. If the Member States decide to grant the EU exclusive competence in a certain area, there is no further place for divagation as to whether and to what extent the necessity of building mutual

\footnotetext{
${ }^{19}$ Grzelak (n 13) 4, 133.

${ }^{20}$ Protocol No 25 to TEU, TFEU [2010] OJ C83/201.

${ }^{21}$ Article 72 (ex Article 64(1) TEC and ex Article 33 TEU) 'This Title shall not affect the exercise of the responsibilities incumbent upon Member States with regard to the maintenance of law and order and the safeguarding of internal security.'
} 
trust is required; this is because the Member States, guided by a will for a certain policy to be effective at a higher level, have already decided to delegate some sovereign rights to supranational organizations. Nevertheless, the act of granting the exclusive powers itself certainly proves the existence of a high degree of trust between the participants of the cooperation.

As far as the principle of mutual trust is concerned, shared competences should be taken into consideration. This sphere of competence should also be analysed in the context of the principle of subsidiarity, which keeps the balance between the EU's intervention and the independent actions of Member States. The EU can intervene only if it is capable of acting more efficiently than the Member States. Thus, in the context of judicial and police cooperation in criminal matters as an area of the shared competences, there is a lot of space for Member States to undertake individual actions. The lack of exclusive competence of supranational organs causes a diversity; this diversity requires, in consequence, the necessity of strengthening mutual trust among all participants.

The application of the principle of mutual trust also depends on the particular moment of creation of the European Criminal Area. This can be illustrated by the example of the basic legal instrument which is used in criminal law cooperation, namely a directive. As far as the creation of common standards by means of directives is concerned, one can distinguish between three distinct stages. The first step is the creation of the EU law; in general this is made through an ordinary legislative procedure involving EU legislators, namely the Council and the European Parliament. The second step is the implementation of EU rules into national systems. The third step is the application of this legislation within individual cases. It is easy to observe that even if there is the political will to create a certain directive among the majority of participants, an individual Member State can destroy the aims of the respective law at the national level, e.g. through incorrect implementation. Furthermore, even with timely and correct implementation, a lack of trust among the authorities applying the law may lead to the complete lack of effectiveness of the EU law. Thus, it seems that mutual trust should be built with particular attention, especially between the organs which apply the law. It can be easier to conclude a pure declaration confirming the readiness for advanced cooperation and the necessity of building mutual trust, or even to adopt concrete measures via the Council and the European Parliament, the EU institutions where people are better acquainted with the EU's policies. The greatest challenge could be to build trust between the thousands of national officials and officers who apply the law every day.

\section{THE PRINCIPLE OF MUTUAL TRUST IN THE JURISPRUDENCE OF THE COURT OF JUSTICE OF THE EU}

The principle of mutual trust is not mentioned in the Treaties. This does not, however, exclude analysis of the legal nature of this principle. In order to justify this approach, the fundamental principle of EU law can be evoked, namely the principle of the primacy of EU law. The Court of Justice 
confirmed its existence in the 1960s, despite the fact that there had never been any specific provision alluding to this in the Treaties. In a pair of crucial judgements, i.e. the Van Gend en $\operatorname{Loos}^{22}$ case in 1963 and Costa v $E N E L^{23}$ in 1964, the Court of Justice held that the Community had constituted a new, separate legal order where the Member States had limited their sovereign rights permanently and in consequence could not establish laws inconsistent with the essence of the Community. Moreover, the application of a law resulting from a treaty cannot be excluded by national law, because this would violate the community nature of the law and would undermine the legal basis for the functioning of the Community ${ }^{24}$. Although the principle of primacy is now unquestionable and has been confirmed by numerous decisions of the Court of Justice, even the last Lisbon reform failed to introduce the binding Treaty principle ${ }^{25}$.

Therefore, the lack of a legal basis in the primary law of the EU does not preclude one from stating that mutual trust is not just a theoretical concept, but also has a normative context ${ }^{26}$. For confirmation of this thesis, a few significant decisions of the Court of Justice can be evoked here.

One of the most important judgements in criminal matters was issued in the case of Gözütok and Brügge $e^{27}$. It was the first judgment issued in the preliminary procedure in criminal matters as well as the first one regarding the interpretation of the Schengen acquis. The Court of Justice stated in the judgment's reasoning that the Contracting States have mutual trust in their criminal justice systems. Consequently, each of them recognizes the criminal law in force in other Member States, even if the application of its own national law would lead to another solution ${ }^{28}$. The Court of Justice confirmed the existence of mutual trust between EU countries, meaning that there is a conviction that the systems of justice in all Member States function efficiently. Moreover, at the same time the Court of Justice emphasized the existence of differences between countries, the fact of which, in its opinion, does not constitute an obstacle for mutual trust. In this particular case, the court ruled that the application by Member States of the principle of ne bis in idem from Article 54 of the CISA ${ }^{29}$, in the context of proceedings leading to the expiry of the public prosecutor's right to investigate, which took place in another Member State without the participation of a court, cannot depend on the fact that the legal system of

${ }^{22}$ Case C-26/62 Van Gend en Loos v Nederlandse Administratie der Belastingen [1963] ECR I-00001.

${ }^{23}$ Case C-6/64 Flaminio Costa v E.N.E.L. [1964] ECR I-00585.

${ }^{24} \mathrm{P}$ Mikłaszewicz, 'Zasada pierwszeństwa prawa wspólnotowego w krajowych porządkach prawnych według orzecznictwa ETS i Sądu Pierwszej Instancji, Omówienie wybranych orzeczeń 1963-2005' (Biuro Trybunału Konstytucyjnego, Zespół Orzecznictwa i Studiów 2005) 3, 4 .

25 ibid 1.

${ }^{26}$ A Grzelak, T Ostropolski, 'System prawa UE. Przestrzeń Wolności, Bezpieczeństwa i Sprawiedliwości UE. Współpraca policyjna i sądowa w sprawach karnych’ in Jan Barcz (ed) vol. XI, part 1 (Warsaw 2009) XI.1-99.

${ }^{27}$ Joint cases C-385/01 Gözütok and Brügge [2003] ECR I-01345, I-1378.

28 ibid section 33 .

29 Convention Implementing the Schengen Agreement, 14 June 1985, between the Governments of the States

of the Benelux Economic Union, the Federal Republic of Germany and the French Republic on the gradual abolition of checks at their common borders [2000] OJ L239. 
the first Member State also does not require the participation of a court in such a case. Thus, if the system of one country does not have a certain legal institution, this state is obliged, based on mutual trust, to recognize the results of the application of the criminal law of another state. The Court stated that this is the only permissible interpretation of Article 54 which enables the effective application of this provision. This interpretation places emphasis on the object and purpose of the ne bis in idem principle, not procedural and purely formal aspects. Such an interpretation is necessary because of the diversity of legal systems within the EU's Member States; and indeed, this diversity should not be an obstacle to cooperation. Furthermore, thanks to the principles of mutual trust, it is not required to undertake a thorough harmonization of the rules in the criminal procedures of the Member States ${ }^{30}$. This broad interpretation of Art. 54 of the CISA in the context of mutual trust has become necessary for the effective application of this provision. This effectiveness has become one of the priorities of the EU, since the Treaty of Amsterdam incorporated the Schengen acquis into the EU acquis. Thus, the Schengen acquis is now one of the objectives within the development of the area of freedom, security and justice.

This ruling constitutes a clear and direct reference to the principle of mutual trust. However, it should be stressed that the Court of Justice only declared the existence of this phenomenon; it didn't create it. It should be noted that the Court's approach in this case is similar to the ruling regarding the issue of mutual recognition concerning one of the economic freedoms, namely the free movement of goods. The Court of Justice, in Cassis de Dijon $^{31}$, also invoked the principle of mutual trust between Member States as a basis for their duty to recognize the different standards that may be present in each state ${ }^{32}$. This judgment was the origin of the broad application of the principle of mutual recognition, as it stated that goods manufactured in accordance with the provisions of one Member State or introduced legally in a certain Member State's economic market should have access to other markets of EU Member States at the same conditions that exist in national ones. This general principle may be limited only in exceptional circumstances and cannot have a discriminatory character, so any such limitations must apply to national products in the same way as to foreign goods. Later, when the mutual recognition principle was already well established within the region's economic integration, it was also adopted in other areas of cooperation. Together with mutual recognition, a necessary precondition, namely mutual trust, has to be achieved. One can assume, thus, that the judgment which expanded and confirmed the application of the principle of mutual recognition and mutual trust for

\footnotetext{
${ }^{30}$ A Gajda, 'Trybunał Sprawiedliwości a III filar Unii Europejskiej' (2006) 2 Kwartalnik Prawa Publicznego 178.

${ }^{31}$ Case C-120/78 Cassis de Dijon - Rewe-Zentrale AG v Bundesmonopolverwaltung fur Brantwein [1979] ECR I-00649.

${ }^{32} \mathrm{~N}$ Thwaites, 'Mutual trust in Criminal Matters: the European Court of Justice gives a first interpretation of a provision of the Convention implementing the Schengen Agreement' (2003) 4(3) European and International Law 260.
} 
cooperation within the former third pillar was that of the Gözütok and Brügge case.

What is of interest to legal scholars is the fact that this judgement is considered to be a form of indirect encouragement towards Member States to harmonize their criminal laws. Similarly, the abovementioned case of Cassis de Dijon prompted the Member States to agree common standards for the admittance of the goods in their markets. The Member States preferred to approximate their standards rather than to trust in different solutions and recognize them all at the same level. Even a partial harmonization can in fact establish minimum guarantees of the common principles $^{33}$. In consequence, this has helped the Member States to treat the foreign goods in the same way as their national products. By way of analogy, we can say that within cooperation in criminal matters such minimal harmonization can help with the implementation of the ne bis in idem principle at the unprecedented, international context ${ }^{34}$.

The significance of the Gözütok and Brügge judgment for the process of building the European Criminal Area is shown by the further practice of the Court of Justice. The Court has evoked the justification of this case very often, in many subsequent criminal cases. However, the revolutionary character of this decision has to be remembered. When this judgement was issued in 2003, criminal law cooperation was still subject to the intergovernmental regime of the third pillar. Thus, this courageous and decisive declaration of the Court concerning the necessity of the principle of mutual trust in so sensitive an area as criminal justice provoked many critical opinions. The main charge levied concerned the fact that the Court, a supranational institution, had started to be engaged intensively in matters where prior to that time it had played a very inconsiderable role. Thus, this ruling also became a catalyst for serious consideration of the communitarisation of the whole former third pillar ${ }^{35}$.

This decision, as already mentioned, has been evoked in many cases within criminal matters. It is also worth discussing here another judgment of the Court of Justice issued during the preliminary ruling procedure in the criminal procedure case against L.H. van Esbroesk ${ }^{36}$. The Court once again interpreted Art. 54 of the CISA and repeated that the principle ne bis in idem means that there is mutual trust between the Contracting States with regard to their criminal justice systems. This is a significant decision as it included the phrase "the same acts" in the context of a provision Art. 54 of the CISA that says: "A person whose trial has been finally disposed of in one Contracting Party may not be prosecuted in another Contracting Party for the same acts (...).' The Court found that the existence of different legal classifications for the same acts in the two countries cannot prevent the ne bis in idem principle from being applied. Due to mutual trust between Member States which compels them recognize certain activities as the same acts, the issue of legal classification is not important. The relevant criterion is the identity of material acts, irrespective of the legal classification or the

\footnotetext{
33 ibid.

${ }^{34}$ H Hinterhofer, European Criminal Law (2011) 51.

35 Thwaites (n 32) 262.

${ }^{36}$ Case C-436/04 Criminal proceeding against L.H. van Esbroesk [2006] ECR I-02333.
} 
legal interest protected ${ }^{37}$. These material acts can be understood as the existence of inextricably linked behaviours. The effective application of the provision requires that the concrete wording of an offence cannot be relevant. It is natural that the legal systems of the EU Member States differ, but this is not an obstacle for the effective implementation of the acquis of the EU. Moreover, as has been already mentioned, the ne bis in idem principle in a unique, international context was incorporated into the EU acquis. It is worth noting here that the application of this principle in international cooperation is an innovative solution in the world and requires the huge commitment and confidence of the Contracting States. Though earlier conventions, such as the International Covenant on Civil and Political Rights ${ }^{38}$ from 1966 and the $7^{\text {th }}$ Protocol $^{39}$ attached to the ECHR, include the ne bis idem principle, it was only applied on the national level. Thus, these conventions declare the prohibition of instituting a new prosecution concerning the same crime under the jurisdiction of a single state. However, they don't prevent other states from initiating further proceedings. In fact, the Council of Europe adopted two conventions in the $1970 \mathrm{~s}^{40}$ introducing the international dimension of the ne bis idem principle, but they have not been ratified by most EU countries ${ }^{41}$ and, therefore, they have only a marginal importance for the doctrine in a practice sense.

The next judgment which is worth evoking here was issued in the preliminary ruling procedure in the criminal case against Dominic Wolzenburg $^{42}$. Advocate General Yves Bot, in his opinion attached to this case, stated that Member States, in agreeing to create a European Judicial Area in criminal matters and, in particular, the system of the European Arrest Warrant based on the principle of mutual recognition, waived a part of their sovereign powers. This renouncement means that they are not able to avoid the situation when the judicial authorities of other Member States institute investigations and prosecutions against their own citizens or to avoid the enforcement of sanctions issued by foreign authorities against their own citizens. The abovementioned Advocate General quoted the preamble of the Framework Decision on the European Arrest Warrant when explaining how this partial waiving of sovereign powers was at all possible. The framework decision provides that 'the mechanism of the European Arrest Warrant is based on a high level of confidence between Member States ${ }^{43}$. The Advocate General concluded that the existence of mutual trust has been confirmed by several measures, inter alia, the withdrawal of the Member States from their right to prosecute in certain circumstances (the ne bis in idem principle as expressed in Art. 54 of the CISA). Yves Bot also cited the abovementioned decision of the Court of Justice issued in the joined cases of Gözütok and Brügge. He stressed that

\footnotetext{
${ }^{37}$ Hinterhofer (n 34) 54.

${ }^{38}$ International Covenant on Civil and Political Rights 1966, Art. $14 \S 7$.

${ }^{39}$ ECHR 1984, Art. 4 of Protocol No 7.

${ }^{40}$ European Convention on the International Validity of Criminal Judgments [1970] CETS No. 070, Art. 53, European Convention on the Transfer of Proceedings in Criminal Matters from [1972] CETS No. 073, Art. 35

${ }^{41}$ Hinterhofer (n 34) 51.

${ }^{42}$ Case C-123/08 Criminal proceeding against Dominik Wolzenburg [2009] ECR I-09621.

${ }^{43}$ Framework Decision of the Council 2002/584/EAW, section 10.
} 
the ne bis in idem principle implies that, irrespective of which rules of sentencing are applied, each Member State has trust in their systems of criminal law and that each of them accepts a potential different outcome of the application of their laws. The analysed opinion concerning the case of Dominic Wolzenburg also provides us with a justification for the existence of mutual trust. He noted that trust among the EU Member States is based on many factors. First of all, each Member State, by acceding to the EU, was obliged to prove the observance of the fundamental rights defined in the European Convention on Human Rights and, since $7^{\text {th }}$ December 2000, also defined in the EU Charter of Fundamental Rights. Moreover, the European Commission in the justification of the draft of the Framework Decision on the EAW, ensured that all Member States share a vision of the rule of law. On the other hand, the confidence which each Member State and its citizens should have in the other Member States' systems is based upon the logical and inevitable consequence of establishing the common market and European citizenship. It is worth noting here an interesting link between the functioning of the single market and the development of effective methods of the cooperation in criminal matters. On the one hand, such advanced economic cooperation can be a source of mutual trust within criminal cooperation. On the other hand, one of the fundamental provisions underpinning the European Criminal Area, namely Art. 54 of the CISA, is going to guarantee the free movement of EU citizens within the single market. The aim of this article is to ensure that no EU citizen that wants to exercise her/his right to free movement can be limited by the threat of consecutive prosecutions for the same acts in several Member States. Thus, both areas of cooperation, in economic and criminal matters, function on the reciprocity principle and they are linked together by strong interdependences.

Yves Bot also emphasized the particular role of mutual trust at the current stage of integration. He stated that due to the lack of thorough harmonization of procedural as well as substantive criminal law, the EU Member States, solely due to the functioning of the principle of mutual trust, can be convinced that the conditions under which their citizens would be prosecuted, tried and convicted in other Member States are at the same standards as the conditions in their own country. Thanks to the principle of mutual trust, the Member States can believe that other Member States will ensure that their citizens will be provided a thorough legal defence, regardless of the lack of knowledge of the language of certain proceedings or the rules of a specific procedure ${ }^{44}$.

To end this analysis of the Court of Justice's approach to mutual trust, I would like to indicate that the national judiciaries of some Member States have also adopted this approach. First, it should be emphasized that the national courts are part of the judicial system within the EU. National judges, therefore, when ruling on matters subject to the EU's legal regime, become EU judges. An interesting judgment showing the influence of the Court of Justice on the national judiciary is the decision of the Polish Supreme Court in $2006^{45}$ concerning the case of Adam G., who was

\footnotetext{
${ }^{44}$ Opinion of the Advocate General attached to case C-123/08 Criminal proceeding against Dominik Wolzenburg [2009] ECR 2009 I-09621, section 136.

${ }^{45}$ Resolution of the Polish Supreme Court (2006) I KZP 21/06.
} 
prosecuted under an EAW issued by the Belgian authorities. In its resolution, the Polish court stated that the admissibility of a negative verification of the conditions under which a particular European Arrest Warrant was issued must be limited to very exceptional cases; it had been already forejudged by the obligation of mutual trust existing between the participants of European integration, the principle which constitutes the foundation of criminal cooperation among EU Member States.

\section{THE LEGAL ASPECT OF MUTUAL TRUST}

Turning now directly to considerations regarding the nature of the principle of mutual trust, one can start from the analysis of another case submitted to the Court of Justice in a preliminary ruling procedure, namely the case instituted by the German court in the course of criminal proceedings against Klaus Bourquain ${ }^{46}$. The opinion of Advocate General Dámaso Ruiz-Jarabo Colomer ${ }^{47}$ is especially of importance here. He stated that though the principle of mutual trust is still novel in the whole concept of the European system of justice in criminal matters, it is however a foundation of the principle of mutual recognition, which undoubtedly constitutes the cornerstone of the emerging European Criminal Area. The Member States stressed this for the first time in the conclusions of the European Council from Tampere in 1999. The existence of mutual trust was also reported in the Council's Framework Decision on the European Arrest Warrant in 2002. In the preamble, it is expressly stated that the required high level of trust has already been achieved ${ }^{48}$.

The Advocate General Damas Ruiz-Jarabo Colomer also noted that the reference to mutual trust in the abovementioned documents was a harbinger of the future significant, already discussed, Court of Justice's judgment in the joint case of Gözütok and Brügge. The Advocate General stated that the Court, at the first opportunity that it could, stressed the importance and obligatory character of mutual trust between Member States. The only possible broad interpretation of Art. 54 of the CISA is justified, in his opinion, by the principle of mutual trust. Thus, he claimed that mutual trust plays a utilitarian role, supporting the principle of mutual recognition ${ }^{49}$. Moreover, the ne bis in idem principle from the abovementioned article is inseparably linked to the requirement of the mutual trust, because regardless of whether the convergence of laws will become a reality someday, the effectiveness of Art. 54 of the CISA does not depend on the approximation of criminal laws of the Member States. He continued that the lack of the approximation can even be considered as an advantage because it compels the Member States to reinforce the scope of mutual trust, to spread common ground where trust can be built ${ }^{50}$.

\footnotetext{
${ }^{46}$ Case C-297/07 Staatsanwaltschaft Regensburg v. Klaus Bourquain [2008] ECR I-09425.

47 Opinion of the Advocate General attached to case C-297/07 Staatsanwaltschaft Regensburg v. Klaus Bourquain [2008] ECR I-09425.

48 ibid section 39.

49 ibid section 41.

50 ibid section 44 .
} 
The Advocate General also raised the issue of the legal character of trust. He noted that, due to the fact there is no need for an approximation of laws, Member States are forced to accept that certain conditions, particularly in the field of fundamental rights, are being met by all participants of the integration. In this situation, he continued, mutual trust becomes a normative principle, one which combines the interpretative rules of the obligations resulting from the former third pillar. The principle of mutual trust thus plays a similar role to that of the principle of sincere cooperation, which has been already included in EU primary law ${ }^{51}$.

One should also mention another judgment issued by the Court of Justice in the preliminary ruling procedure in the case of Gasparini ${ }^{52}$. The Dutch court asked the EU Court to determine whether the ne bis in idem principle, enshrined in Art. 54 of the CISA, applies to the decision of a court of a Contracting State which acquitted the accused due to the crime's period of prescription. The Court stated that in Art. 54 there is no reference to the particular content of the final judgment, thus there is no reason to interpret it in a restrictive way and limited its application only to convictions. The aim of Art. 54 of the CISA is the unlimited exercise of the freedom of movement by all EU citizens, including persons who were prosecuted and whose case was processed. The fear that new proceedings can be instituted against the same acts in another Member State is an inadmissible obstacle. At the same time, the Court of Justice noted that the degree of harmonization of criminal laws is insignificant, e.g. in this particular case, national laws concerning prescription periods are not comparable. However, no article of the EU Treaties or the Schengen Agreement or the CISA make the application of the Art. 54 dependent on such harmonization. In scholars' comments on the judgment, it was said that the Court of Justice took a maximalist approach to mutual trust, departing from the opinion of Advocate General Sharpston who stated, on the contrary, that the concept of mutual trust is not a reasonable basis for the broad application of the ne bis in idem principle in relation to ordering the dismissal of the prosecution because of a crime's limitation period ${ }^{53}$.

\section{THE LIMITATION OF THE PRINCIPLE OF MUTUAL TRUST}

One can ask whether advanced European integration requires unlimited trust from the Member States, as well as whether it is necessary or even desirable to have integration or a general crime prevention policy. As part of this paper's consideration of mutual trust, I would like to analyze the interdependences between the principle of mutual trust and the effectiveness of the emerging European Criminal Area.

In most scientific studies, scholars' opinions on a pro-integration, pro-EU approach can be found, emphasizing the effectiveness of new legal solutions. Thus, the restrained behaviour of some Member States is strongly criticized as a factor limiting the efficiency of criminal policies and the development of building the European Criminal Area. It is stressed that a

\footnotetext{
51 ibid section 45 .

${ }^{52}$ Case C-467/04 Gasparini [2006] ECR I-09199.
} 
new dimension of advanced integration has also brought about new opportunities for the development of pathological phenomena, for the expansion of more dangerous criminal activity. Thus, the instruments which are to fight this phenomena also have to enter a new dimension of supranational cooperation. A European Criminal Area based on the principle of mutual recognition and mutual trust is considered the most effective answer for increasingly frequent global crimes as well as crimes resulting from the unique form of the integration and the openness of the Member States. However, there is also another side of the European Criminal Area and the functioning of its fundamental principles which are very often forgotten ${ }^{54}$ : threats which can emerge once the European Criminal Area is fully realized. In this section, I would like to take into consideration a certain paradox, namely the link between strengthening cooperation and increasing the threat to the creation the area of freedom, security and justice. It should be noted that ill-considered integration between unprepared parties can badly affect crime prevention policies. One can enumerate, inter alia, the threat of bureaucratic opportunism, the abuse of fundamental rights and difficulties with taking responsibility for executing punishments at the European level ${ }^{55}$.

However, one cannot argue that the EU seeks to strengthen cooperation between its Member States expecting mindless automatism, mere blind trust ${ }^{56}$. The judgment issued in the case of criminal proceedings against Filomeno Mario Miraglia ${ }^{57}$ clearly shows that the Court of Justice put equivalent emphasis on the effective application of the principle of ne bis in idem based on the requirement of mutual trust, as it did on the efficient functioning of justice within the EU enabling the escape from criminal responsibility. Consequently, the Court of Justice found a balanced solution. On the one hand, the Court repeated the need for a broad interpretation of the ne bis in idem principle of Art. 54 of the CISA in order to avoid a situation where a person, through the freedom of movement, would be threatened by a subsequent prosecution for the same act in another Member State. On the other hand, the Court emphasized that this principle cannot be applicable to decisions issued without any examination of the merits. In the Miraglia case, the proceedings were ended by the prosecutor's decision only because of the previous institution of the criminal proceedings in another Member State against the same defendant for the same act. However, such a decision, according to the Court, cannot constitute a final judgment in the sense of Art. 54 of the CISA. The alternative interpretation would hamper the sanctioning of any punishable acts.

It may appear, in the practice of the functioning national authorities, that there is a risk of blind trust, of dangerous routine. The system established by the European Arrest Warrant based on a high level of trust can illustrate this threat. However, while the respective framework decision

\footnotetext{
${ }^{54}$ Ch Ecks, Th Konstadinides, Crime within the Area of Freedom, Security and Justice. A European Public Order (CUP 2012) 216.

${ }^{55} \mathrm{Z}$ Brodecki, Europa sędziów (LexisNexis 2001) 26.

${ }^{56}$ Grzelak, Ostropolski (n 26) XI.1-120.

${ }^{57}$ Case C-469/03 Criminal proceeding against Filomeno Mario Miraglia [2005] ECR I0200 .
} 
requires the proper control of each issued EAW in every situation, it does not always prevent mistakes due to automatism. To demonstrate this, the case of Praczijk can be evoked. He was a Belgian who was surrendered by his national authority at the request of the Italian organ. When he was arrested and sent to Italy, it was found that there was a mistake and the Italian authorities released him. The Belgian authorities stated that were not responsible for the mistake and they were not obliged to pay any compensation, evoking as the justification the principle and duty of mutual trust $^{58}$.

Therefore, it is said that the observance of the principle of mutual trust does not require absolute confidence. This trust can be defined as conditional $^{59}$, meaning that we can only speak of possible mutual trust within the EU thanks to many integrative factors such as the relative homogeneity of the standards of European legal systems, the identity of fundamental principles, and common interests arising from the geographical location of states. However, the existence and extent of this trust is not finally determined and it depends on further action to be undertaken by the interested parties ${ }^{60}$.

\section{THE PROBLEM OF VIOLATION OF MUTUAL TRUST BY AN EU MEMBER STATE}

The effects of a lack of trust within cooperation can be manifested at the level of the creation of the law as well as its application. First, the lack of confidence can be shown by the incorrect, limiting implementation of various legal instruments or significant delays in the transposition of the EU acts to national legislation. Secondly, the over-controlling approach of the enforcing organs to the legal instruments coming from other Member States or the extensive interpretation of the exclusion from mutual recognition can hamper the whole process of cooperation.

The consequences of lack of trust can be analyzed in two different situations. On the one hand, it should be considered in the context of further cooperation between states. The Member States often refer to the principle of reciprocity. Thus, a breach of trust by one party leads, in general, to the same behaviour of the other, even though it is stated in doctrine that the source of the EU Member States' obligation to fulfil the agreed tasks can no longer be derived from the reciprocity principle. The EU has already entered into a more advanced stage of integration and the traditional rule of reciprocal behaviours has already lost relevance. The source of EU Member States' obligations is now the common aspiration to remain loyal to the agreed obligations and to ensure that the European Criminal Area materializes. Therefore, of more relevance is the principle of sincere cooperation from Art. $4 \S 3$ TEU which, in the opinion of some scholars, has replaced the traditional rule followed in international relations, namely the

\footnotetext{
58 A Weyembergh, 'Wzajemne uznawanie orzeczeń w sprawach karnych - bilans Europejskiej Przestrzeni Sądowej' in A Frąckowiak-Adamska, R Grzeszczak, Europejska Przestrzeń Sądowa (Wydawnictwo Uniwersytetu Wrocławskiego 2010) 56.

${ }^{59}$ Ficher (n 4) 13.

60 ibid 13.
} 
reciprocity principle ${ }^{61}$. However, some examples have shown that reciprocity is enshrined very deeply within international cooperation, and also remains so between EU Member States. Additionally, even though reciprocity is to be substituted, there are still some remnants of this traditional principle. The problem with the implementation of the EAW in Germany shows this clearly. The German Constitutional Court found ${ }^{62}$ that the legislation transposing the EAW is unconstitutional and invalidated $\mathrm{it}^{63}$. From that moment until the entry into force of the new law, Germany did not adhere to the EAW system. In such circumstances, some Member States refused to act upon German warrants, referring directly to the principle of reciprocity. They claimed that if Germany did not comply with the principle of mutual trust, it cannot be expected that other countries will surrender their citizens ${ }^{64}$. Thus, the situation blocked cooperation in this particular field, but it could also have had more far-reaching consequences for the development of the whole criminal area, undermining the credibility of one of the parties.

The lack of trust can be also manifested in the way laws are implemented. One can take into consideration the example of the Polish legislation transposing the Framework Decision on the EAW. It should be noted that the first attempt of the Polish legislator, similar to the German approach, was recognized by the Constitutional Tribunal as unconstitutional ${ }^{65}$. The Polish Constitution, in the former Art. $55 \S 1$, stated that the extradition of a Polish citizen is prohibited. The legislator tried to justify its proposal, saying that the EAW was a completely different form of cooperation than extradition. However, the Constitutional Tribunal concluded that both instruments, the traditional extradition as well as the EAW, have an identical essence. Ultimately, the legislator was forced to change the constitution. The new version of Article 55 of the Polish Constitution $^{66}$ enables a Polish citizen to be surrendered under certain conditions, generally including the dual criminality requirement. However, it is said that such a solution does not provide full compliance with the Framework Decision on the EAW. It allows a departure from the verification of double criminality only in cases when a respective person is a foreigner. The framework decision differentiates situations when the dual criminality requirement exists or not, based only on the type of crime, not the nationality of the prosecuted person ${ }^{67}$.

It should also be noted that there are further doubts with regard to the Polish implementation of the decision which relate to the provisions concerning the possible refusal to enforce specific EAWs. The directive provides three obligatory situations, whereas the Polish Code of Criminal Procedure ${ }^{68}$ includes six and one of them relates to political crime (Art. 607 p par. 1 sec. 6); the EU legislation liquidated the political condition. It

\footnotetext{
${ }^{61}$ A Grzelak, M Królikowski, A Sakowicz, Europejskie Prawo Karne (CH Beck 2012) 58.

${ }^{62}$ Judgement of the Federal Constitutional Tribunal of 18.05.2005.

${ }^{63} \mathrm{H}$ Saztger, International and European Criminal Law (CH Beck 2012) 121.

${ }^{64} \mathrm{H}$ Kuczyńska, Wspólny obszar postepowania karnego w prawie UE (Scholar 2008) 164.

65 Judgement of the Polish Constitutional Tribunal of 27.04.2005, P I/05

${ }^{66}$ Official Journal of Poland (2006) No. 200, position 1471.

${ }^{67}$ Grzelak, Ostropolski (n 26) XI.1-108.

${ }^{68}$ Polish Code of Criminal Procedure [2013] OJ 1529, item 480.
} 
seems that the Polish implementation remains one step behind in comparison to the newest EU solutions. What is more, the Polish Code adds a second paragraph to Art. $607 \mathrm{p}$, where the criterion of the citizenships is included. This addition comprises another obligatory condition in the situation where a respective person is Polish and the crime was committed on Polish territory. The directive provides territory rules only within the facultative conditions of refusal and does not make it dependent on citizenship. One can draw the conclusion that such differences in national legislations, the lack of the full conformity with the EU directive and the lack of consistency within all 28 Member States' solutions can lead to mistrust, to the undesired differentiation of the situations of EU citizens.

\section{CONCLUSION}

Based on the Court of Justice's jurisprudence and the practice of Member States, one can assume that a normative character of the principle of mutual trust has emerged. However, it cannot be allowed to prevent the continuous development of the foundations of this trust between Member States. The normative character of the principle enables Member States to better execute their obligations. However, the principle of mutual trust should not become a static rule. On the contrary, it should be the subject of constant progress. Recognition of the elaborated normative character cannot be synonymous with the abandonment of efforts by the EU and its Member States to build and strengthen the foundations of mutual trust. Normativity of the principle, along with realization in practice, can lead to the full creation of the European Criminal Area. It should also be emphasized that the recognition of the normative character of trust within the EU can have significant importance in other contexts, especially in the diversity of the process of building mutual trust and the lack of homogeneity in this area. It has already been stated that the level of trust currently achieved varies significantly in certain areas of cooperation, policy or even concrete legal instruments. In such a situation, the normativity of this principle shall guarantee equal standards within the whole European Criminal Area. 